\title{
Ethnologies
}

\section{Stages of busi(-)ness and identity}

\section{Geoff Lightfoot et Valérie Fournier}

Volume 24, numéro 1, 2002

\section{Espace}

Space

URI : https://id.erudit.org/iderudit/006538ar

DOI : https://doi.org/10.7202/006538ar

Aller au sommaire du numéro

\section{Éditeur(s)}

Association Canadienne d'Ethnologie et de Folklore

ISSN

1481-5974 (imprimé)

1708-0401 (numérique)

Découvrir la revue

Citer cet article

Lightfoot, G. \& Fournier, V. (2002). Stages of busi(-)ness and identity. Ethnologies, 24(1), 225-249. https://doi.org/10.7202/006538ar

\section{Résumé de l'article}

Cet article examine la manière dont est mobilisé l'espace dans le cadre de " l'entreprise familiale ». Le concept même d'entreprise familiale fait s'effondrer quelques distinctions profondément établies dans les sociétés occidentales modernes, celles entre maison et travail, public et privé, vie de famille et raisons d'affaires, distinctions qui cartographient l'espace au moyen de frontières établies entre l'espace de travail et l'espace familial, la maison et le bureau. L'entreprise familiale, en particulier lorsqu'elle est menée à la maison, fait tomber les barrières de cette conception de l'ordonnancement spatial lorsque les images familiales et la scène de l'entreprise se confondent. Notre analyse d'une petite entreprise familiale de pension canine porte sur la manière dont l'espace est utilisé pour encadrer différentes scènes d'action. Nous avons recours, en particulier, à des métaphores théâtrales pour explorer la manière dont le travail entre dans la mise en scène des identités et des relations sociales. Tout d'abord, nous discutons des relations entre l'espace, les scènes, l'action et l'identité dans une optique théâtrale ; ensuite, à partir des matériaux de notre étude de terrain sur cette petite entreprise familiale de pension canine, nous examinons la manière dont les

propriétaires-entrepreneurs utilisent l'espace comme une ressource malléable qui leur permet de découper et d'assembler différentes scènes afin de se présenter eux-mêmes et de présenter leur entreprise à différents publics. Après être revenus au théâtre pour discuter de l'importance de la mise en scène dans l'assemblage cohérent des histoires de l'entreprise familiale ou au niveau dramatique, nous terminons par l'exploration des limites de la métaphore théâtrale pour l'analyse de la vie sociale.
Ce document est protégé par la loi sur le droit d'auteur. L'utilisation des services d'Érudit (y compris la reproduction) est assujettie à sa politique d'utilisation que vous pouvez consulter en ligne.

https://apropos.erudit.org/fr/usagers/politique-dutilisation/ 


\title{
StAGES OF BUSI(-)NESS AND IDENTITY
}

\author{
Geoff Lightfoot, Valérie Fournier \\ Centre for Social Theory and Technology \\ Keele University
}

Once upon a time in the EastEnd... Peggy, in between pulling pints behind the bar of her pub, looks across to Grant, her son, and Tiffany, her daughter-in-law: "It's worth having you two back together again", she says, "even if it has cost me a barmaid".

Bianca, Tiffany's best friend is not so sure. "That Grant, he's an animal", she claims when Tiffany visits her on her market stall. Bianca's father, David (who had put up the initial money to open her stall) had come off worst in violent encounters with Grant and his brother, Phil. Further down the market, Gita and Sanjay (the stallholders Bianca used to work for) are having problems of their own. Simon, their employee, has attracted the unwelcome attentions of a gang of young hooligans, out for a bit of queer-bashing. Tony, his partner, had caught the worst of it, being beaten up while walking through the market on the way to Ian's chip shop. Ian, whose wife had affairs with both of his stepbrothers, had bought the chip shop for his wife. Now, the thugs, causing mischief all around the Square, had sprayed graffiti on the chippie's window. Ian, upset, canvassed the Square's residents, trying to persuade them to form a neighbourhood watch to deal with the new problem.

His cousin Mark, now running the fruit and veg. stall previously owned by his uncle, was sympathetic, although his more pressing concern was the procedures involved in becoming a foster parent. For the Beales, the gang problem was also close to home. Mark's wife, Ruth (who worked in the local nursery), was able to comfort Pauline, her mother-in-law, when she had to go to the police station to hear her youngest son receive 
a formal caution for burglary (carried out with a similar gang). Pauline was worried about taking time off work but Carol was able to cover for her in the launderette where they both worked. Carol realised the potential problems for her and her husband, Alan, have only recently got back together after Alan moved in with Frankie, a singer at Alan's all night café.

Kath, Ian's mother, who runs the café by day, also employs Alan's mother, Blossom. This is slightly awkward as Ted, her brother, was due in court for assaulting Robbie, Carol's son. Ted was very upset, both by the imminent court appearance and the impending failure of his business (the hardware shop), so Kath asked him and her husband, Phil, out for a drink (in the Queen Victoria). Ted reacted angrily to jibes from Phil about the limited future of independent hardware shops, claiming that, "At least my business is on the level". This hit home for Phil only recently escaped legal retribution for dodgy dealings at his garage. That time, Ricky, his employee was left to carry the can.

Ricky's other business, the car lot he had shares in with his stepbrother and Pat, his stepmother, has now folded (partly because Barry, another one of Pat's stepsons, torched the office caravan). Barry has since set up a new business - executive car-hire - on the same site as the car lot, although he has needed some help from Roy, his father (finance and cars) and Pat (to help out on the radio). Pat was an ideal choice for she had run a cab firm from the caravan while Frank, her ex-husband, had run the car lot. Normally, however, Robbie mans the radio, placing work for Huw and Lenny. Huw and Lenny are busy, for, when they're not minicabbing, they're behind the bar at the newly reopened Cobra club.

The Cobra club was the site for much EastEnd criminality. Not only was the Cobra where Tony engaged in a little "informal business" - drug-dealing to club-goers - but the very ownership of the club seems to be of borderline legality. George appears to have passed matters to his daughter, along with a new print shop on the site of Felix's barbershop, but has tried to keep the new ownership hidden. There are obviously further dodgy dealings to be uncovered: George has warned Tony off (in his job as local newspaper reporter) any investigation of his affairs. As yet, Peggy (George's "lover") is unaware of any underhand goings-on although both Peggy's sons, Grant and Phil, no strangers to 
criminality, remain suspicious and give him at best a cautious greeting when he appears in the Vic.

This brief summary of a few weeks plot in EastEnders from some time ago has illuminated the EastEnd stages as much as some of the intriguingly interlinked relationships that are squeezed in between the main members of the cast. These stages - the small businesses and family businesses where the cast meet and play out their dramas - are normally available only as sites for dramatic action. An actor might be spotted leaving Mark's stall, clutching a brown paper bag, before Mark engages with one of the core cast members. Another actor might be seen behind Gita and Sanjay, browsing through clothing, oblivious to the row in front. Grant, Tiffany, Peggy or - once — Lorraine might serve another actor a drink in the Queen Victoria before reanimating the marital drama behind the bar. Secondary actors can be spotted lurking in the shops, neither speaking nor purchasing, but demonstrating that these businesses are trading.

In some ways the sites are essential — a small incredulity to maintain the credulity of the larger theatre. No one in the cast leaves Walford to go to work in the City or West End - they are all self-employed, small business owners or working in one of the other small businesses in the Square. Despite some $50 \%$ of the workforce being employed in smaller enterprises in the UK (Hakim 1989; Goss 1991), it is unlikely any urban community would be so concentrated among the petite bourgeoisie and their employees. Yet without this centring of the business and employment within the families and the community, the scriptwriters soon run out of plausible sites to meet and interact.

Mainly, these EastEnd businesses are little more than sophisticated, animated props. They are the main sites for action, they open up opportunities for social encounters around which the plot can unfold. In that, they are more convenient than the more visibly "home" settings where the opportunity for the meeting of characters outside the family is more limited. But, as the soap drags in its surroundings to make them part of the story, these stages also become part of the action. Sometimes academic models are played out on the EastEnders stage. We see some of the traditional research problems of small and family businesses, of inheritance, of failure, of the break-up of partnerships, of the conflict between entrepreneurial action and business morality. However, perhaps surprisingly, given the limited number of stories that can be woven 
around the same characters, there has been little exploration of the potential clash between family and business, even though this is frequently seen as the family business problem in academic writing (Chandler 1990; Cromie and Adams 1997).

The very concept of a "family business" blurs the boundaries between firmly established, distinct spaces in Western modern societies: that of the home and family on the one hand and that of work and business on the other (Wheelock and Oughton 1996). As such, the concept collapses a series of polarities around which much of modern life and modern social science get organised: public and private; rational and emotional; work and pleasure. The framing of this spatial blurring into a "problem" where the "family" becomes a source of difficulty for the "business" defines much of the literature on the family business (incidentally an approach that decisively places "business" as more important than "family"). As a result, the family business becomes a puzzle, an anomaly, in organisational and management research, despite substantial historical records suggesting that the collapse of family and business is in many ways the archetype of smaller enterprise (e.g. Crossick and Gerhard-Haupt 1995; Hareven 1991).

The troublesome "family business" disrupts a sense of distinct and ordered space, a disruption exacerbated when the business is run from the family home. Family businesses run from the home unstick the "proper order of space": they conflate and mix up different repertoires and images. The language of business is replete with concerns over time: illustrated both in common sense parlance such as "time is money" and academic frameworks related to life-cycles and stages of business development. It is as if business existed mainly through its movement in time: marked by the modernist obsession for progress, it emphasises the process of becoming, of temporality at the expense of spatiality. Space is reduced to a contingent category (Harvey 1989). Conversely, the image of the family home is invested with powerful myths about the poetics of space (Bachelard 1964) the home is the space of timeless, fixed, motionless childhood memories, a space where time gets suspended. Images of home emphasise being in space, as opposed to becoming through time.

Given the powerful myths attached to "home" and "business" and the different repertoires on which they build, it is perhaps not surprising that conventional analyses of family businesses seek to bring order to 
the recalcitrant space of the family business, to reerect boundaries, to discipline the family, leaving the business uncorrupted by "sentiments" or personal relationships. For example, owner-managers are urged to establish a sense of distance between the home and the business (e.g. Nelton 1986) so that every activity falls back into some ordered space and time, as if there was a natural time and space for everything. When, as invariably happens, the distinction between family and business cannot be reestablished, this is treated as problematic and as the cause of difficulty for the business. Whilst conventional research on family business pays scant attention to the role of space in structuring social and power relations, in giving meaning to social practice and identity, it is based on some fundamental (and in our view flawed) assumptions about the nature of space, assumptions which blind such research to the details through which "family business" is performed. In this respect, research on family business replicates much of modern social science's treatment of space and its often implicit presumption. As Agnew (1993) suggests, the conceptualisation of space that seems to pervades much social science is that of a given backdrop against which action can take place, or a set of fixed containers, naturally dividing social action and relationships into different spheres. Thus it is assumed that space is an objective and universal attribute, offering natural boundaries independently of social practices, that there is a time and place for everything (e.g. Harvey 1989). From such perspective, all activities have to be slotted into the "right time and place".

There are several problems with such an approach. Firstly, it assumes a universal view of time and space which has become discredited in both the natural and social science:

Neither time nor space, the physicists now broadly propose, had existence (let alone meaning) before matter; the objective qualities of physical time-space cannot be understood, therefore, independently of the qualities of material processes (Harvey 1989: 203).

Similarly, anthropological studies have indicated that our sense of time and space is not universally and objectively fixed but is shaped by social, cultural and material practices:

The conclusion we should draw is that neither time nor space can be assigned objective meaning independently of material processes, and that it is only through investigation of the latter that we can properly ground our conceptions of the former... From this materialist 
perspective we can then argue that objective conceptions of time and space are necessarily created through material practices and processes which serve to reproduce social life (Harvey 1989: 204).

In this article, we follow Harvey $(1989,1996)$ and others (e.g. Thrift 1996) in seeing space as socially constructed, we attend to the material and symbolic practices through which space is given meanings by being transformed into stages of action, and we explore how these stages then frame social interactions and identities.

Secondly, as hinted above, research based on the assumption of fixed and objective time and space is ill-equipped to make sense of the activity of family businesses. By casting owner-managers into set roles and onto pre-fixed stages defined through time and space, such research cannot but dredge up the stale finding that family businesses do not abide by these allegedly natural time-space categories, and therefore are fundamentally flawed. Indeed, even a casual viewing of a soap, such as EastEnders, shows how such boundaries can be so diminished as to make any crossing routine enough to escape notice until it is deliberately changed from scenery to plot. In addition, any such approach fails to see how owner-managers use time and space as a resource to create certain effects, to perform certain identities and frame particular actions. Meanings get attached to the business through spatial inscription, owner-managers perform the "sort of person they are", the "business", the "family" partly through the assembling, unmaking, lightening and darkening of stages. As we shall suggest in this article, whilst the blurring of family and business is experienced as a problem by family business owners, seeing this "problem" as the result of the transgression of "natural boundaries" between some set spaces of home and business, and focusing merely on implications for the profitability of the business, obfuscates the everyday practices and work that go into constructing boundaries to protect not only the business from the family, but also the family from the business. Moreover, the obsession with keeping the family out of the business characteristic of much of the family business literature serves to obscure the ways in which the family can become a resource for the business, a resource that is, at least partly, mobilised spatially by playing on the proximity between family home and business. When the family does get acknowledged as a "resource", this is reinscribed in concerns about growth and profitability, again obscuring our understanding of the work and practices invested in staging the "family-ness" of the business, in performing "family" and 
"business" as being at times closely intertwined, at others separated (Fournier and Lightfoot 1997).

The spatial performance of "family business" - the ways in which family and business are staged, held together and held apart through spatial construction - constitutes the main focus of this article. To study the relationship between space, identity and performance, we use the metaphor of the theatre and draw upon a dramaturgical tradition already well established in the social sciences (e.g. Burke 1945; Goffman 1969, 1974) and to a lesser extent in organisational studies (e.g. Mangham and Overington 1987).

In what follows, we first discuss the relationships between space, stages, performance and identity through a theatrical lens; we then draw upon material from our study of family run boarding kennels to explore how owner-managers construct and use space as a malleable resource from which they carve out and assemble different stages to perform their business and themselves to different audiences. After going back into the theatre to discuss the role of stages in weaving together coherent stories in the family business or in drama, we close by exploring the limitations of the theatrical metaphor for the analysis of social life.

\section{Space, Identity and Performance}

The spatial dimension of social and power relations has long been recognised in geography, and in particular in "minority" geographies where power relations are seen as being inscribed and stabilised through spatial ordering, for example through the creation of core and margin (e.g. Hetherington 1996; Law 1994; Massey 1994; Rose 1993). For example, gender relations and division of labour are mapped on the construction of the "home", its interior organisation of space, and its division from the "public sphere" (e.g. Cott 1977; Harvey 1996). Relationships and conflicts between various social groups, defined and divided along lines of gender, class or ethnicity, have been played out, partly, in space (Harvey 1996); not only through its physical appropriation, but more significantly for our purpose here, through its remarking, through contest over who gets to use "space", for what purpose, what it comes to represent to different groups. For example, urban spaces get transformed as they are (re)appropriated by different groups and put to different uses, inscribed with different meanings (Czarniawska and Solli 2001). The contested deployment of space brings 
into relief its highly malleable and flexible nature; space is "rife with possibilities" (Czarniawska and Solli 2001).

This open-ended nature of space is well captured by Harvey's (1996) discussion of the social construction of space in terms of "carving out permanences", and Thrift's (1996) notion of spatial formation. With these notions, both Harvey and Thrift seek to emphasise the closely interwoven nature of social action and space, each being constitutive of the other. For Harvey, turning space into meaningful sites of social action involves the creation of "permanences", the mapping and stabilisation of social ordering and relationships into particular spatial arrangements:

Such permanences come to occupy a piece of space in an exclusive way (for a time) and thereby define a place - their place - (for a time). The process of place formation is a process of carving out "permanences" from the flow of processes creating spatio-temporality. But the "permanences" — no matter how solid they may seem — are not eternal but always subject to time as "perpetual perishing". They are contingent on the processes that create, sustain and dissolve them (Harvey 1996: 261).

Space is relational in that unless it is embedded in social practice, it remains meaningless, empty. It is shaped into "permanences", stages or meaningful action through social processes; only when it has been inscribed with meaning can it add its "weight" to the maintenance and framing of social ordering, and even then, only "for a time". For example, the "house" only acquires its "homeliness" through the work of separation done by the door, the wall, the closing of the curtains (Simmel 1994) that keep the "public eye" at bay; only then can it become constructed as the repository of sentiments, intimacy, warmth; and only then can this spatial demarcation be enrolled in the reproduction of gender relations and division of labour.

Whilst the constructed and relational nature of space is gaining grounds in social sciences, it seems to be quickly forgotten to give way to the more conventional treatment of space as a pre-constituted and fixed backdrop for action (Harvey 1996). It seems that in order to do justice to the socially constructed nature of space, we need to attend to the processes, the work that goes into carving space into stages of meaningful action, "permanences". This is where the theatrical metaphor may be of particular relevance. Indeed, it is the theatre that has perhaps 
come most closely to grips with the construction of "stages", the mobilisation of space to evoke certain meanings, social relations and identities. As Brook (1972) suggests, the starting point of any theatrical performance is an "empty space"; the stage has to be filled and constructed to evoke the characters and the meanings of the play, the mobilisation of space is essential to the performance.

The theatrical metaphor emphasises the malleable texture of space and leads us to examine how the stage is constructed to evoke certain social relations and identities, how various stages are assembled, darkened, put under light in order to "conjure up voices and realms" (Torode 1977), to represent (make present) certain meanings, and to call forth certain characters.

With the idea of the "bare stage", Brook (1972) suggests that the stage does not acquire life or meaning of its own, it has to be constructed. The "empty space" (Brook 1972) has to be filled visually and discursively to mark social relationships and characters, to delineate "invisible" boundaries and demarcate distinct spheres of action and interaction. Space is organised to structure and symbolise relationships (e.g. distance and movement), to signal hierarchy (e.g. periphery and centre), and to convey something about the characters, the sorts of persons they are. For example, intimacy has to be produced spatially by staging distance and movement between characters.

However, the process of staging has to be effaced so that we as spectators or audience of a play are willing to suspend belief for a while, to forget that this is acting, to be taken in by the impression of "naturalness". Brook (1972) uses the notion of the holy theatre to talk about this process of creation of "naturalness", of representing (or making present) the invisible. He gives the powerful example of Voodoo dancing where the wooden totem serves as the channel through which the invisible holy spirit is making itself present and visible as it passes through the wood into the body of one of the dancers. Similarly, in the theatre, the director has to rely on material symbolisation of the invisible, of those meanings that cannot be directly shown and pointed to; just as the "holy" loses its "holiness" by appearing as staged, meanings become empty if they are represented in such a way that the work of representation, the staging, remains apparent.

The theatrical metaphor turns our attention to the work, processes, details through which meanings and characters are brought to life, to 
the ways social relationships are framed by being transported onto different stages, to the processes through which the "naturalness" of the staged reality is accomplished, through which "performance" is transformed into the taken for granted (Mangham and Overington 1987). The theatrical metaphor is apposite for exploring the setting up of business stages, for just as the theatrical board, the space of the family business has to be infused with meanings that cannot be communicated directly without appearing "staged", "false", meanings that can only be brought to life if they are staged in such a way the staging disappears. In the next section, we explore the staging work that goes into the performance of business and family in small family run boarding kennels.

\section{Building the Stages, Preparing the Props}

As the theatre director, the owner-managers of our boarding kennels start with a unfilled stage, an empty space which has to be mobilised in ways that signal to potential audiences, principally customers, that this is the place where they should be happy to leave their pets. We can see some of this happening as we spend time with one owner-manager. In what follows, we offer an impressionistic account of the spatial performance of meanings in one boarding kennel; this account is based on a combination of participant observation and interviews with the owner-managers (Mr and Mrs G.).

The importance of space in the making of boarding kennels is made clear by the many statutory regulations specifying the minimum size of the pens, and the number of "isolation pens" that kennels must provide in case of illness. However, attracting an audience takes more than merely having pens and runs of the required size, it takes some staging. The staging and setting not only signify that this is a boarding kennels (not, say, a farm or somebody's backyard) but also speak for the sort of kennels we are entering. Spatial ordering serves to attach meanings and values to the boarding kennels.

The boarding kennels are set in the country and the countryside itself — all rolling fields, country lanes and grazing cattle — creates the initial backdrop. This country setting performs some important identity work for it evokes images of rural tranquillity (important as most of the kennels visited serve large urban areas), and of simplicity and freedom (helpful when the animals are to be caged for a fortnight). This stage remains visible during most of our stay whenever we are outside. Indeed, 
there are constant props to maintain this country fiction: the hanging baskets and boot-scrapers outside the doors are readily recognisable through the pages of magazines such as Country Living. This image of country living, of closeness to nature (and by extension animals) is reinforced by the filling of the stage with the owners' own dogs. On entering the kennels, we are greeted by several barking dogs running between the house and the kennels building, suggesting that for the owner-managers running a kennels is not just a money-making business but an extension of personal interests and fondness for dogs. The presence of the owners' dogs serves to tone down the business nature of the relationship with customers and to transform it into a more intimate family to family relationship (between customers and their pets, and owner-managers and their pets). Intimacy is also performed by the proximity of the family house to the kennels, and their convergence onto the courtyard; the pets' buildings are enclosed into the family space.

The proximity of the home speaks of constant attention to the pets, of the inclusion of the pets in the owners' family. The mapping over of family and business space tells customers that they are not just dropping their pets in a business but leaving them in the care of a family. "Familiness", symbolised through the proximity of the home and the scattering of icons of family life (the dogs, the garden, children's toys and bikes), serves as a particularly powerful resource in a "caring" business such as boarding kennels.

Yet it would be wrong to overplay this rural and homely idyll. The picturesque setting is but one part of the backdrop - the opening stage is much more complex. In many ways the full stage erected is that of a farm: ugly, utilitarian buildings of concrete and steel pasted alongside the weathered brick and tile of the family home. To some extent the kennel owner-managers embody this farming imagery by dressing like farmers, talking like farmers. Of course, farmers have an ambiguous image, mixing attachment to nature with a more ruthless exploitation of land and resources (Abrahams 1991). This ambiguity is also reflected in the boarding kennels. Competing with the homely images of the kennels and the pleasant settings are stern instructions at the gates about opening times, a dark and bare cabin that serves as an office, all reminding us that there is still business carried out here. 
The presence of the "office" speaks of the officialness of the place, it gives it a "professional" touch, and with it, a glow of reliability and trustworthiness. Moreover, the office serves to establish some distance between the family and the business, a point developed later. The layout of the new purpose-built kennels also signals professionalism: the standardised and individual indoor pens opening, through the operation of a hatch, onto separate outdoor runs clearly speak of conscious design, not amateur ham-fistedness. The clinical cleanliness and tidiness of the pens further disturb the family feel experienced on entering the kennels. There is a sense of emptiness about the place for the "cells" are bare except for a plastic tub (for the dogs to sleep in) and separated from one another by metal bars. This bareness and austerity strip the place of any intimacy, marking the kennels as a cold and functional affair, as a Brutalist setting for a business. However, even in this sterile environment, as we shall see later, various props can be brought out to enliven the place, to stage cosiness and sentimental attachment to the dogs.

As we enter the boarding kennels for the first time, the stage is still inchoate, the importance of many of the props undetermined. It is only when Mrs G. moves onto and between the stages that the weighty import of different artefacts that litter the site start to become apparent. Her actions and movements serve to illuminate the various props lying around, taking us onto certain stages and pulling us away from others. It is through her work of assembling, lighting, darkening stages, that different patterns of actions and social relationships emerge, that for example customers are reassured that they are leaving their pets in "caring hands", but then also reminded that this is a business where caring is performed for a fee, or that family members are transformed into "economic resources".

As we have suggested in the short description above, there is no absolute, fixed delineation between family and business; family and business spaces are mapped over each another and into the spaces occupied by the other. As already mentioned, the owners' dogs running between the house and the kennel buildings serve to collapse home and business into one stage. These lines of movement connecting family and business are also drawn daily by family members working in the business. Whilst the kennels is run by Mrs G., all family members (husband, daughter and son) are brought in to help; the daughter is responsible for cleaning the cattery and preparing the cats' food before 
going to school, the husband and son are brought in to "do what needs doing". Family and business spaces are also brought together by their convergence onto the common courtyard. This conflation of home and business spaces calls for careful spatial management, or staging, on the part of Mrs. G. Indeed, in her spatial work, she is treading a fine line between evoking the familial and commercial nature of the business, between performing the family and the business as both near and distant. As Mrs G. opens the door from the family home and steps directly onto the common space, she emphasises the nearness of the family stage to the business stage. A series of visible and invisible family images follow in her footsteps; she might be accompanied by her own pets or by other people in her family, immediately identified as such. However, the proximity of home and business is to some extent undermined by the ambiguity of her movement from the family stage onto the general stage. At the same time as she is including the family as a prop within the wider stage, she is dimming the lights behind her (closing the door to the family home), excluding the prurient audience from examination of the family behind the scenes. Whilst her movement from the home performs the familial nature of the business, customers are invited to follow in her footsteps away from the home.

Through her movements, her actions (e.g. the closing of the door) and the props she scatters along, Mrs G. weaves places together, she demarcates distinct stages and then collapses them. This fluidity is also illustrated by the ways in which the same physical space can be transformed into different stages, with the lightening of various artefacts and the presence of different audiences. In the morning, she is able to show us the utilitarian kennels, clinically clean and purposive, bare metal pens and unpainted walls, but the same kennels become a place for the display of affection to dogs with the presence of customers later in the day.

In the morning, the building is treated as a place to be run "economically", to be cleaned of "dogs' muck"; there is little touching of, or talking to, the dogs; when addressed at all, the dogs are called "you" ("shut up you" seems to be the favourite line during this cleaning work) and not by their names, creating distance between Mrs G. and the "animals". Family relations are here deployed as business resources to be used efficiently. Whilst Mrs G. initially frames her daughter's daily work in the cattery within a familial setting by stressing the opportunities it affords her to earn pocket money, she later explained how she had to 
discipline her daughter into behaving "economically", stressing that this was not the place for the display of affection to "animals". The relationship between Mrs G. and her husband also takes a different turn as it is transported from the home to the business. Whilst at home, husband and wife discuss and make decisions about the business "together", often around the evening meal taken at the family table; in the kennels, Mr G. becomes a helping hand that is deployed at Mrs G.'s call, "where needed".

But this stage of cold instrumentality gets transformed into a caring place during "opening hours" when customers walk in. Some of the props left in the dark while Mrs G. was cleaning come under light with the presence of an audience, the customers, and serve to attach some warmth and intimacy to the boarding kennels. For example, a handwritten card with the name of the dog and of the owner is attached on the door of each pen. These name cards speak about the sort of treatment the dogs receive as one marked by closeness and intimacy; the dogs are not just objects to be cleaned and fed but become full characters with a name and a "home". With the construction of these two different stages (cleaning, showing the customers around), we can also see a division being set up between backstage and frontstage. The "wiping of the board clean" in preparation for the performance to the audience constitutes the backstage and remains invisible to the customers. The marking of the pens as backstage, as a forbidden place, during cleaning time is reinforced by the locking of buildings to prevent customers from walking in without Mrs. G.'s prior authorisation. When the customers are visiting, the pens get transformed into the frontstage, a place where intimacy and closeness to the pets are performed to a welcome audience. However, this distinction between backstage and frontstage, between the staging of instrumentality and caring, is not always easily maintained. As we have already seen with the case of Mrs. G.'s daughter, family members may forget what stage they're performing on, and have to be brought back to their place. Customers may also walk astray, undermining Mrs G.'s work to construct and demarcate different stages. Whilst Mrs G. is eager to stress that she "has nothing to hide", that the kennels are an "open place" that customers are welcome to visit and inspect, she can hardly hide her frustration with customers forgetting their place and walking in outside opening hours, or trying to come into the house. As she keeps reminding us, the customers can be problematic, sometimes straying from their assigned business roles 
and attempting, directly or indirectly, to invade family space and time. The overt darkening of the restricted family stage and the illumination of business areas, instructs the customer on their allotted spaces. Her locking of the kennels doors behind her, the pulling of the curtains in the house, the building of an "office" outside the home, are all part of her staging work, of her attempts to construct and demarcate stages of action and social relations.

As the account above suggests, the ordering of space into different stages is not just about evoking particular images of the business to the customers; it also serves to define and structure social and power relationships. Mrs G. is skilful at deploying and setting up stages to frame her relationships with different audiences. For example, relationships with customers are quickly established as "business relationships" (as opposed to family relationships) by being transported to the office or the courtyard. Whilst on approaching the boarding kennels, all one can see is the house and pets building (the office remains invisible until one walks all the way to the end of the courtyard) leaving an impression of family feel and intimacy, on walking more closely towards the buildings, the house is clearly marked as a forbidden place to the customers by the presence of the office lurking on the other side of the ground. The stage marked off as the "office" (it has a sign saying "office" on the door, it also has a sign saying "closed/open") is a purpose built wooden cabin planted in between the cats' and dogs' buildings.

This separate stage is bare of the frilly fripperies of family life; it is a small and dark room containing two wooden stools and a built in table for only furniture. By escorting customers away from the house to the office, she is placing customers in a setting where monetary transactions, which co-exist uneasily with family relationships, can more easily take place. She is signalling the formal nature of the relationship, but also placing the customer within a business role which limits the freedom that a more informal and personal role might allow. The shifting emphasis in the relationships with customers from the familial nature of the service to a business transaction is enacted spatially, by walking the customer to the office where money is exchanged, accounts are settled. But this money does not stay in the cold and distant office for long; it is earmarked for the children's benefits: it is what enables the family to keep ponies for the children. Money acquires different meanings, embodies different social relationships as it moves from the kennel to the office, and from the office to the home; it is reconfigured by the stages on which it plays. 
As Zelizer (1994) argues, money is not an empty, cold commodity, it gets marked with shifting meanings as it is inscribed in different social relations; money gets earmarked for weddings, for old age, for the children, for rainy days... And as we see with the case of Mrs G., these shifts in meaning and usage are mapped over different spatial domains (Harvey 1996).

The bare setting of the office also performs an effect of size and a feel for the business. The only things on the table are the telephone and her two diaries (one for cats and one for dogs). Mrs G. points out that the office does not have a computer because she is "only a small kennel, no a multimillion pounds company", "it doesn't warrant a computer or complicated paperwork". All the business is represented in the two diaries which also constitute most of her paperwork. The small and simple character of the business, and the down-to-earth, "no frills" approach of its owner-manager, are all inscribed in the plain look of the office.

As we follow Mrs G. through various stages, other facets of her character become apparent. In particular, she is skilful at staging her power and centrality in the (her) business. She is able to place herself at the centre of the stage, displaying her knowledge, skills and organisation of resources. All of the props, the scenery and the stages are organised around her - she is the one who gives them meaning. Sometimes this is through her practised movements around these stages, locking and unlocking doors, leading us from one area to another, pulling us in behind her, captive audience to her skilled manipulation of the space within the kennels. At other times it is through mobilisation of the props to hand: sitting behind the desk; opening the ledgers and diaries; an easy familiarity with different animals, together summoning up an image of adept professional and business skills. Mrs G. also emerges as the central character through the positioning work she does. Whilst her husband, daughter and son all help in the kennels, their contributions are made peripheral by their casting away from the stage in which she is performing. They always seem to be confined to whatever space she is not in at the time; she monopolises the stage by pulling it all to herself.

The daughter is confined to the cattery, the husband and son don't even have their "own place"; they are deployed wherever "she needs them"; she is running the show, placing and moving the actors onto different stages. Maybe the most powerful way in which Mrs G. performs 
the centrality of her character is through the darkening of the stages she steps out of. Each building is locked each time she comes out (even if she returns to that building some minutes later). This obsessive locking of doors serves to darken the stage she leaves; the stages she is not on are made redundant whilst the stage she enters is lit up by her unlocking of the door, thus ensuring that the performance cannot go on without her; the stages and the performance revolve around her.

Finally Mrs G. is keen to portray herself as busy, and the assembling of different stages also assists in this performance of busy-ness. The construction of multiple stages, all requiring her presence, creates a sense of constant "in between-ness" and "busy-ness", there is always another stage to go to; when performance on a stage is over, another one is calling her. Even when she retreats into the home for a break, it is only for coming back out onto another stage. The different stages serve to establish a sense of always being "in movement", there is no stage on which she can linger and rest.

She also performs "busy-ness" by delineating an empty space and then filling it in again, thus creating an image of escape from the stage as an impossible dream. The 12.30 to 5.30 stage is defined by its emptiness, by its lack; this is the time (stage) when the kennels are closed to customers, when the cleaning and feeding have been completed, and when the children (at least for some of the time) are still at school. Yet this time remains elusive; it slips away when one tries to look in and gets transformed into stages of busy-ness and movement.

When describing what happens during these 5 hours (and longer during quiet times), Mrs G. punctuates this period with various activities; she finishes at 12.30 and by the time she gets in and has lunch it's 2 p.m. (making an hour an a half, or 4 hours during quiet times suddenly slip away), and then at 2 p.m. she soon has to go and pick up the children (3.30). The stage is closed off but forced open by an audience (in this case ourselves) trying to look in. By filling the "empty space", she conjures up an image of constant busy-ness. The bare stage is set into motion by the unwelcome intrusion of an audience (the children, ourselves, some "disrespectful customers"...) she has to perform for. However, it is not just the audience who intrudes on the bare stage and sets her into action, it is also her mind; Mrs G. talks about the fact that even when all the work has been covered and she goes away during the 
day, her mind is still in the kennels. Movement away does not free her from performing, her mind is still trapped on the stage.

\section{Losing the Plot, Holding the Stage}

This brief account of a family business illustrates the way in which stages punctuate the day, give life to different characters, frame different patterns of action and relationships, and tell of different stories and characters. We have used the theatrical metaphor to capture "doing owner-manager" as a performance and concentrated on staging - e.g. construction of appropriate settings, movement between stages, darkening of redundant stages - as one of the central processes through which meanings, relationships and identities are performed.

The conflation of home and business acts as a significant resource in this staging work, but one that requires careful and constant management, as actors (customers or family members) may crop up in the wrong place, forgetting their part and undermining Mrs G.'s staging work. As much of the family business literature warns us, the blurring of family home and business is, at times, experienced as a problem by owner-managers. However the condemnatory note with which such warning is issued ignores the considerable amount of effort that is invested in, at times, constructing boundaries between home and business, at others effacing these boundaries. The "problem" is not that family businesses transgress some natural boundaries between home and business - as tends to be the focus of the family business literature - but that they cannot rely on practices associated with modern employment, such as travelling from home to work, to order and organise their lives into different spheres. Whilst the physical separation between "work" and "home", or "family" and "business" in modern employment practices acts as a convenient device to define and demarcate different stages of social practice and relations, those who are running a business from home, or the increasing number of people teleworking (Mirchandani 1998), cannot rely on this device to divide their lives. As such, their practices and experiences bring into relief the work that has to go into "spatial formations", into constituting and demarcating different spheres of activity and relations. And as we have seen with the case of Mrs G., such work of ordering, or separating, does not always line up with or reproduce the modern divisions between work and home, family and business. 
In seeking to understand the work that goes into constructing, demarcating, and blurring different stages of action, we have found the theatrical metaphor particularly useful as it alerts us to the malleability of space, its endless potentiality for giving life to different meanings and patterns of social relations, but also to the active work of staging that is required for an "empty space" to be turned and stabilised into a meaningful site of action. The theatrical metaphor has a long tradition in the social sciences, perhaps because the detachment implied in exerting a sociological imagination resonates strongly with a "Brechtian" distance. Goffman, for example $(1969,1974)$, did much to popularise the theatrical model for the analysis of social practices although his innovative analysis overshadows the work of Burke (1945) which he drew upon. Burke put forward a useful dramaturgical framework for making sense of everyday and social practice; he suggested that "coherence" emerges out of the interweaving of five theatrical elements (the pentad):

... in any rounded statement about motives, you must have some word that names the act (names what took place, in thought or deed), and another that names the scene (the background of the act, the situation in which it occurred); also you must indicate what person or kind of person (agent) performed the act, what means or instruments he (sic) used (agency), and the purpose (Burke 1945).

For Burke (1945), any script (theatrical or social) implies a "sceneact" ratio in which the scene or setting "both realistically reflects the course of action and symbolises it". Stories and meanings are performed through the mobilisation and assembling of modes of dressing, accessories, action and stages, each element acquiring meaning in the context of the others, and giving meaning to the others. Thus space and the props scattered around the boarding kennels only acquire meanings with Mrs G.'s presence, with her acting, staging, work; she weaves them together into coherent patterns that emerge as stages performing familiar meanings. Through the country and homely setting, the kennels speak of family feel, intimacy; through the hidden office, the layout of the new pens and their cleanliness, we are reminded that this family run kennels is also a professional business. The making of the kennels is an achievement performed partly through the assembling of heterogeneous materials into stages that bring invisible meanings to life, meanings are realised through their inscription in space (Brook 1972). 
Staging is also central to the making of the character. The different characters that Mrs G. plays to various audiences (e.g. mum with the children, a down-to-earth business owner-manager with the customers in the office, and a dog-lover while showing the pens to customers) are not self-evident but are announced and framed by her movement through and onto different stages. This movement and positioning becomes central to identity work. Power relationships between Mrs G. and customers, or other family members, are played out through the appropriation of space (e.g. the locking of doors, the peripheralisation of family members, the confinement of customers to the small and hidden office).

In EastEnders, however, spatial location becomes less important as the story frequently appears to exist above and beyond the settings. Actors are assembled together in first one location, then another, positioned in a series of sites that enable interaction between the participants. It then becomes clear that the location is typically not central to the plot: providing the superficial logic of the characters allows them to be in a location, then it can become a workable site for interaction. EastEnders, then, in cynically using business settings as stages for social and family interaction, demonstrates the slipperiness of the stages, and the facility by which actors can be directed from one site to another while retaining some credibility.

At times, the same slipperiness was evident in the boarding kennels where family and business stages, backstage and frontstage get transmuted into one another. Through the skilful production work of the owner-manager we find that we cannot cling to the certainty that there is "a place for everything". As we start to see some dividing line between frontstage and backstage, Mrs G. dissolves such distinction by insisting she has nothing to hide. Family and business spaces are wrapped around one another, tightly interwoven in one continuous yarn.

In EastEnders, each stage is complete. Simon and Tony live in their flat, Gita and Sanjay live in their flat. Simon, Sanjay and Gita work on their stall in the market. Each of these settings is defined, prewritten and whole. The actors may perform a few peripheral actions - pulling a pint, serving a customer - necessary because of the setting, but they do not need to work at closing off different stages, at showing that they are on one stage and not another. Mrs G., however, works with a greater fluidity. Her stages do dissolve and run into one another. Sometimes she tries to construct an image of strong family values and identity by 
carving out some distinctive and "private" family spaces. However, these "family spaces" are always disrupted, they can be breached, allowed to blend in with the business. No fixed boundary can be maintained in this constantly shifting ground.

Maybe it is not surprising, then, that Mrs G. has to look outside or to imaginary places to provide the setting for family unity, by drawing upon traditional family myths and images, or by physically moving away from the premises. The frequent references to the evening meal taken together at the family table conjures up an image of family introspection, of the family as a cosy and protective nest to which each member can withdraw for warmth and support. This image of the family heart and hearth is reinforced by Mrs G. insisting on marking the house as a forbidden place to the customers (or any "strangers"). The image of the family meal also symbolises strong moral values about family duties, and about avoiding the temptation of the wasteful pleasures and idleness rampant in the outside world. This theme has echoed through the aspirations of the petite bourgeoisie since the nineteenth century, where the enclosing of the family into the private space of the home served to distinguish it from the working class and to mark its attachment to the bourgeoisie by stressing the value of hard work and family duties against the common pleasures of drinking or playing in the street (Crossick and Gerhard-Haupt 1995). However, the family meal remains an image that is never materialised as it is constantly disrupted by customers phoning in. Yet, even in the disruption, the image of family can continue to be evoked as these customers are the disruption, rather than the meal disrupting the business.

Elsewhere, the image of the "happy family unity" is also created by the daily drive away from the premises to the children's ponies. Here again, the sense of family unity is created by carving out a space away from the business, by mum driving the children to their ponies in the morning (for feeding), in the evening (for training) and occasionally at weekend for competition. However, even then the business clings on, trails behind them; Mrs G. is keen to stress that it is only thanks to the boarding kennels that the family can afford to keep the ponies for the children, this time creating a happy coincidence between the business and family unity. Thus even when Mrs G. tries to erect some boundaries between business and family spaces, it is only to see them washed away, sometimes in a happy harmony, other times with a sense of disruption to the family unity. 
Some of the elements in the creation of the stage in the boarding kennels have clearly recognisable social meanings that can be drawn upon without further work - the house as a home, for example. Other props are initially neutral - any business/kennels meaning and importance has to be constructed for the audience's benefit. These more discreet props only have a power to impress in the setting that Mrs G. has provided. Thus, the emphasis on work implied by the dress code of Wellingtons and jeans only makes sense once the practical, physical aspects of the kennels business have also been demonstrated. The division of the kennel space into a variety of different stages can only be done by the owner-manager, can only make sense once done by the owner-manager. As part of this, it can be seen that props and scenery are not just frill or decoration, but are central to the plot. Mrs. G. lets the story unfold through the scenery, constantly shifting the materials and the meaning of those materials to produce working sites for different interaction and characters.

This is a clear contrast with the overtly theatrical traditions in EastEnders. In the soap, the settings and stages are far less flexible and fluid. Typically, on the business stages, only the props and equipment that make the business immediately apparent as a business are used, and these props are in ready supply. Tills, beer pumps, clothes for sale, mechanics tools, frying pans and tea urns are all recognisable aids and helpfully distributed around the set. There is no doubt, as soon as the scene opens, as to the relative positions and roles of the actors. Customers are shown approaching the business, determined in advance to buy. The actors do not have to, and therefore normally do not, mobilise additional materials to emphasise their business identities, to sell themselves within the business.

The clarity of the stages in the soap makes movement between them easy to achieve; it only needs the switch of the camera for us to be transported to a new scene of action and drama. In the boarding kennels, movement between stages is never so clear and easy, it needs to be traced by the footsteps of the owner-manager, it requires labouring; Mrs G. has to work on the production of the new stage she enters to bring it to life; it is not already and self-evidently set. The props, like the kitchen table, have to have their standing continually reinvoked.

Moreover, in the theatre or EastEnders, there is a closing of the stage; we are willing to suspend belief and immerse ourselves in the 
stories for a while but we know there will be an end. After the last drawing of the curtains, the stage will be dismantled and vanish, the actors will become free to "be themselves" (although, of course, for us at least, part of their identity will always be wrapped in the characters they played). But there is no closing of the stage for the owner-manager of the family business; some of the stages may be temporarily darkened but they do not and cannot disappear. Mrs G. may play different characters but there is no escape toward "real self", no stepping outside the roles she has to play. There is no freedom from the stage: walking into the wings from one stage merely places her in front of a different curtain. 


\section{References}

Abrahams, Ray. 1991. A Place of Their Own: Family Farming in Finland. Cambridge: Cambridge University Press.

Agnew, John. 1993. Representing space: Space, scale and culture in social science, in Place, Culture, Representation, eds. James Duncan and David Ley. London, Routledge: 251-271.

Bachelard, Gaston. 1964. The Poetic of Space. Boston: Beacon Press. Brook, Peter. 1972. The Empty Space. Harmondsworth: Penguin.

Burke, Kenneth. 1945. A Grammar of Motives. Englewoods, Cliffs: Prentice Hall.

Certeau, Michel de. 1984. The Practice of Everyday Life. Berkeley: University of California Press.

Chandler, Alfred. 1990. Scale and Scope: The Dynamics of Industrial Capitalism. Cambridge, MA: Belknap Press.

Cott, Nancy. 1977. The Bonds of Womanhood: "Women's sphere" in New England, 1780-1935. New Haven, Conn.

Cromie, Stanley and John Adams. 1997. Management Succession in Family Firms: The challenge of change, in Small Firms: Entrepreneurship in the Nineties, eds. David Deakins, Peter Jennings and Colin Mason. London, Chapman: 61-71.

Crossick, Geoffrey and Heinz Gerhard-Haupt. 1995. The petite bourgeoisie in Europe 1970-1914. London: Routledge.

Czarniawska, Barbara and Rolf Solli, eds. 2001. Organizing Metropolitan Space and Discourse. Malmo: Liber.

Douglas, Mary. 1966. Purity and Danger. London: Routledge.

Fournier, Valerie and Geoff Lightfoot. 1997. Identity work and family business. In Small firms: Enterprising futures, eds. Monder Ram, David

Deakins and David Smallborne. London, Chapman: 22-32.

Goffman, Erving. 1969. The Presentation of Self in Everyday Life. London: Allen Lane, Penguin.

Goffman, Erving. 1974. Frame Analysis. Cambridge, Mass.: Harvard University Press.

Goss, David. 1991. Small Business and Society. London: Routledge. Hakim, Catherine. 1989. Identifying fast growth small firms. Employment Gazette, January: 29-41.

Hareven, Tarama. 1991. The history of the family and the complexity of social change. American Historical Review 96 (1): 95-124.

Harre, Rom. 1979. Social Being, 2nd ed. Oxford: Blackwell. Harvey, David.1989. The Condition of Postmodernity. Cambridge, Mass.: Blackwell. 
- 1996. Justice, Nature $\mathcal{E}$ the Geography of Difference. Oxford: Blackwell.

Hetherington, Keith. 1996. Identity Formation, Space and Social Centrality, Theory, Culture and Society 13(4): 33-52.

Law, John. 1994. Organizing modernity. Oxford: Blackwell.

Mangham, Ian and Michael Overington. 1987. Organization as theatre:

A social psychology of dramatic appearance. Chichester: Wiley.

Massey, Doreen. 1994. Space, Place and Gender. Cambridge: Polity Press. Moore, Henrietta. 1986. Space, Text and Gender. Cambridge: Cambridge University Press.

Nelton, Susan. 1986. In Love and in Business. New York: Wiley.

Rose, Gill. 1993. Feminism and Geography: The limits of geographical knowledge. Cambridge: Polity Press.

Thrift, Nigel. 1996. Spatial Formations. London: Sage.

Torode, Brian. 1977. The revelation of a theory of the social world as grammar, in Life sentences, ed. Rom Harre. Chichester, Wylie: 8797.

Wheelock, Jane and Elisabeth Oughton. 1996. The household as a focus of research, Journal of Economic Issues, 30 (1): 143-159.

Zelizer, Viviana. 1994. The creation of domestic currencies, American Economic Review, 84 (2): 138-142. 